\title{
Downhill running and exercise in hot environments increase leukocyte Hsp72 (HSPA1A) and Hsp90 $\alpha$ (HSPC1) gene transcripts
}

\author{
James A. Tuttle, ${ }^{1}$ Paul C. Castle, ${ }^{1}$ Alan J. Metcalfe,,${ }^{1,4}$ Adrian W. Midgley, ${ }^{3}$ Lee Taylor, ${ }^{1 *}$ \\ and Mark P. Lewis ${ }^{2 *}$ \\ ${ }^{1}$ Muscle Cellular and Molecular Physiology Research Group, Institute of Sport and Physical Activity Research, Department \\ of Sport Science and Physical Activity, University of Bedfordshire, Bedford, United Kingdom; ${ }^{2}$ National Centre for Sport and \\ Exercise Medicine, School of Sport, Exercise and Health Sciences, Loughborough University, Loughborough, United \\ Kingdom; ${ }^{3}$ Department of Sport and Physical Activity, Edgehill University, Ormskirk, United Kingdom; and ${ }^{4}$ School of \\ Exercise and Health Sciences, Edith Cowan University, Perth, Australia
}

Submitted 6 May 2014; accepted in final form 18 February 2015

Tuttle JA, Castle PC, Metcalfe AJ, Midgley AW, Taylor L, Lewis MP. Downhill running and exercise in hot environments increase leukocyte Hsp72 (HSPA1A) and Hsp90 $\alpha$ (HSPC1) gene transcripts. J Appl Physiol 118: 996-1005, 2015. First published February 26, 2015; doi:10.1152/japplphysiol.00387.2014.--Stressors within humans and other species activate Hsp72 and Hsp90 $\alpha$ mRNA transcription, although it is unclear which environmental temperature or treadmill gradient induces the largest increase. To determine the optimal stressor for priming the Hsp system, physically active but not heat-acclimated participants $(19.8 \pm 1.9$ and $20.9 \pm 3.6 \mathrm{yr})$ exercised at lactate threshold in either temperate $\left(20^{\circ} \mathrm{C}, 50 \%\right.$ relative humidity; $\mathrm{RH})$ or hot $\left(30^{\circ} \mathrm{C}, 50 \% \mathrm{RH}\right)$ environmental conditions. Within each condition, participants completed a flat running (temperate flat or hot flat) and a downhill running (temperate downhill or hot downhill) experimental trial in a randomized counterbalanced order separated by at least 7 days. Venous blood samples were taken immediately before (basal), immediately after exercise, and 3 and $24 \mathrm{~h}$ postexercise. RNA was extracted from leukocytes and RT-quantitative PCR conducted to determine Hsp72 and Hsp90 $\alpha$ mRNA relative expression. Leukocyte Hsp72 mRNA was increased immediately after exercise following downhill running $(1.9 \pm 0.9$-fold $)$ compared with flat running $(1.3 \pm$ 0.4 -fold; $P=0.001)$ and in hot $(1.9 \pm 0.6$-fold $)$ compared with temperate conditions $(1.1 \pm 0.5$-fold; $P=0.003)$. Leukocyte $\mathrm{Hsp} 90 \alpha$ mRNA increased immediately after exercise following downhill running $(1.4 \pm 0.8$-fold $)$ compared with flat running $(0.9 \pm 0.6$-fold; $P=$ $0.002)$ and in hot $(1.6 \pm 1.0$-fold $)$ compared with temperate conditions $(0.9 \pm 0.6$-fold; $P=0.003)$. Downhill running and exercise in hot conditions induced the largest stimuli for leukocyte Hsp72 and Hsp90 $\alpha$ mRNA increases.

heat shock response; exercise heat stress; thermotolerance

THE HEAT SHOCK PROTEIN (HSP) system has a crucial role in acquired thermotolerance via the protein chaperone (22) and antiapoptotic functions (3) of HSP72 (commonly known as HSPA1A) and HSP90 $\alpha$ (HSPC1). Modulation of kinase signaling along with assembly of gene transcription and protein translation machinery by $\mathrm{HSP} 90 \alpha$ is also a crucial aspect of both the cellular stress response and cellular adaptation to exercise heat stress $(54,61)$. These functions help attenuate the pathophysiological events (tissue damage and the systemic

\footnotetext{
* L. Taylor and M. P. Lewis are to be considered senior authors of this article.

Address for reprint requests and other correspondence: J. A. Tuttle, Muscle Cellular and Molecular Physiology Research Group, Institute of Sport and Physical Activity Research, Dept. of Sport Science and Physical Activity, Univ. of Bedfordshire, Bedford, United Kingdom (e-mail: james.tuttle1987 @ gmail.com).
}

inflammatory response syndrome) associated with multiorgan failure syndrome, which is central within exercise heat stress and exertional heat illness-specific morbidity and mortality (13). Both HSP72 and HSP90 $\alpha$ protein concentrations are elevated proportionally to increased cellular stress (increased cellular temperature) following ex vivo heat shock (39). Therefore, elucidating the in vivo cellular stressor(s), which induces the largest Hsp 72 and Hsp $90 \alpha$ mRNA, increases could indicate the stressor(s) most likely to elevate HSP72 and HSP90 $\alpha$ protein concentrations and, thus, potentially attenuate exertional heat illness risk by developing a thermotolerant phenotype. This thermotolerance, from a whole body perspective, may include delaying thermal injury (33) by elevating the core body temperature during exercise heat stress at which exercise becomes physiologically limited (1). For practical purposes, this could enhance athletic performance and extend occupational pursuits (fire-fighting, industrial work, and military training or operations) in challenging (hot and humid) environments.

Induction of Hsp72 mRNA occurs following exercise (69), exercise-induced muscle damage (EIMD) (52), and exercise heat stress (44), while Hsp $90 \alpha$ mRNA is induced after exercise $(12,38)$ and exercise heat stress (44). These stressors were measured in isolation, precluding interstudy comparison because exercise intensity (34) and duration (58), environmental conditions (40), participant training state (46), sampling time courses, tissue of interest, and measurement techniques [Northern blot analysis, RT-quantitative PCR (RT-QPCR), and gene arrays] that were used to measure Hsp72 and Hsp90 $\alpha$ mRNA were not standardized. Consequently, the most appropriate stressor or combination of stressors (e.g., downhill running and exercise heat stress) to increase Hsp72 and Hsp90 $\alpha$ mRNA transcription (and, thus, potentially enhance thermotolerance via elevated basal HSP72 and HSP90 $\alpha$ protein concentrations) following an acute preconditioning stressor was unknown.

Therefore, the primary purpose of the current study was to determine the environmental temperatures and treadmill gradients (singularly and in combination; downhill running in a hot environment) that induced the largest leukocyte Hsp72 and Hsp90 $\alpha$ mRNA increases. The current study also aimed to determine the physiological [rectal temperature $\left(\mathrm{T}_{\mathrm{re}}\right)$ and heart rate $(\mathrm{HR})]$ and perceptual responses (delayed onset muscle soreness, DOMS) to each condition to determine the physiological stressors associated with Hsp72 and Hsp90 $\alpha$ mRNA induction. It was hypothesized that downhill running 
Table 1. Participant demographic characteristics

\begin{tabular}{lccc}
\hline \hline & $\begin{array}{c}\text { Temperate Group } \\
\text { (TEMP) }\end{array}$ & $\begin{array}{c}\text { Hot Group } \\
\text { (HOT) }\end{array}$ & $\begin{array}{c}\text { Group Significance } \\
(P<0.05)\end{array}$ \\
\hline Age, yr & $19.8 \pm 1.9$ & $20.9 \pm 3.6$ & $P=0.563$ \\
Height, m & $1.8 \pm 0.1$ & $1.74 \pm 0.05$ & $P=0.398$ \\
Body weight, kg & $71.7 \pm 7.4$ & $70.9 \pm 10.4$ & $P=0.880$ \\
$\dot{V}_{2 m a x}, \mathrm{ml} \cdot \mathrm{kg}^{-1} \cdot \mathrm{min}^{-1}$ & $55.6 \pm 5.7$ & $55.5 \pm 5.3$ & $P=0.991$ \\
$\%$ Lean mass & $87.0 \pm 8.1$ & $87.2 \pm 5.5$ & $P=0.507$ \\
$\%$ Body Fat & $13.0 \pm 8.1$ & $12.8 \pm 5.5$ & $P=0.951$ \\
Training, hr/wk & $2.4 \pm 0.8$ & $2.6 \pm 0.5$ & $P=0.689$ \\
\hline
\end{tabular}

Values are expressed as means $\pm \mathrm{SD}$. $\dot{\mathrm{V}}_{2 \max }$, maximum oxygen uptake.

and exercise within hot environmental conditions would offer the greatest stimuli to increase Hsp72 and Hsp90 $\alpha$ mRNA. Therefore, downhill running in a hot environment would be the best condition to induce $\mathrm{Hsp} 72$ and $\mathrm{Hsp} 90 \alpha$ mRNA transcription.

\section{METHODS}

\section{Ethical Approval}

The protocol was approved by the University of Bedfordshire's Sport and Exercise Science Departmental Human Ethics Committee, and all participants signed informed consent in accordance with the ethical standards outlined in the 1964 Declaration of Helsinki.

\section{Participants}

Demographic variables were recorded in a population of 14 male Caucasian participants who were team game players and were nonsmokers (see Table 1). All of the participants were not accustomed to downhill running or regular eccentric exercise and were not heatacclimated [testing conducted between December and March within the United Kingdom; average temperature range was $1.5^{\circ} \mathrm{C}-7.9^{\circ} \mathrm{C}$ (41)]. Body mass ( $\mathrm{kg}$ ) and height $(\mathrm{cm})$ were measured using mechanical scales (Weylux Marsden 424, London, UK) and a stadiometer (Harpenden HAR-98.602, Crymych, UK), respectively. Body composition was measured using air displacement plethysmology (Bod Pod 2000A, Cranlea, UK). The lactate threshold (LT) and maximum oxygen uptake $\left(\mathrm{V}_{2}\right.$ max $)$ were determined using a graded treadmill test (30). This test consisted of 6-8 incremental 3-min stages at a $1 \%$ gradient. Participants started running at $8-9 \mathrm{~km} / \mathrm{h}$, and running velocity was increased by $1 \mathrm{~km} / \mathrm{h}$ per stage until exhaustion (30). Finger tip capillary blood samples $(40 \mu \mathrm{l})$ were taken at rest and at the end of each 3-min stage to determine blood lactate concentrations $(\mathrm{B}[\mathrm{La}])$. Blood lactate concentrations were plotted against running velocity to determine LT, which was defined as the first sustained $\mathrm{B}[\mathrm{La}]$ increase above baseline (30). Pulmonary gas exchange was measured breath by breath using an online gas analysis system (Cortex Metalyser 3B, Biophysik, Leipzig, Germany) to determine changes in oxygen uptake $\left(\mathrm{V}_{2}\right)$ with the highest $\dot{\mathrm{V}}_{2}$ attained over a 30 -s period accepted as $\dot{\mathrm{V}}_{\mathrm{O}_{2} \max }(30)$.

Participants ran at the running velocity, which elicited their individualized LT during the graded treadmill test throughout the flat running trials. For the downhill running trials, participants exercised at the running velocity that required the same oxygen uptake as running at the LT during flat running (1\% gradient). This was determined during familiarization and was typically $3-3.5 \mathrm{~km} / \mathrm{h}$ faster than LT on a $1 \%$ gradient. This velocity was maintained throughout each downhill running trial. This difference between flat and downhill running is similar to that found in previous literature (51).

Sample size calculations were determined a priori (G.Power 3.1, Universität Dusseldorf, Germany) (14) for exercising $\mathrm{T}_{\mathrm{re}}, \mathrm{HR}$ (31) and Hsp72 mRNA (49) using data from previous papers. Two-tailed tests with alpha set at 0.05 and power at 0.8 suggested that a sample size of six was required within each group to detect significant $(P<$ $0.05)$ differences in exercising $\mathrm{T}_{\mathrm{re}}\left(0.8^{\circ} \mathrm{C}\right)$ and $\mathrm{HR}$ ( 7 beats $\left./ \mathrm{min}\right)$ between environmental conditions and an Hsp72 mRNA increase of $489 \%$ between basal (immediately before exercise) and immediately after exercise.

\section{Experimental Design}

Participants were split into two groups that exercised in different environmental conditions (see Fig. 1).

The temperate environmental condition featured two experimental trials separated by 7 days: 1 ) the temperate flat (TEMP FLAT $_{\text {) }}$ experimental trial involved $30 \mathrm{~min}$ of running at the LT on a $1 \%$ gradient in $20^{\circ} \mathrm{C}, 50 \% \mathrm{RH}$; and 2 ) the temperate downhill (TEMP $\left.{ }_{\text {Down }}\right)$ experimental trial involved 30 min downhill running at the LT on a $-10 \%$ gradient to induce muscle damage (14) in $20^{\circ} \mathrm{C}, 50 \% \mathrm{RH}$.

The hot environmental condition featured two experimental trials separated by 7 days: 1 ) The hot flat $\left(\mathrm{HOT}_{\mathrm{FLAT}}\right)$ experimental trial involved 30 min of running at the $\mathrm{LT}$ on a $1 \%$ gradient in $30^{\circ} \mathrm{C}, 50 \%$ $\mathrm{RH}$; and 2) The hot downhill ( $\mathrm{HOT}_{\text {DOwN }}$ ) experimental trial, which involved 30 min of downhill running at the LT on a $-10 \%$ gradient to induce muscle damage (14) in $30^{\circ} \mathrm{C}, 50 \% \mathrm{RH}$.

A counterbalanced experimental design was used in which the experimental trials were completed in a randomized order, at the same time of day and at the running velocity, which elicited the LT to minimize differences in metabolic strain between individuals (6). However, environmental temperature-mediated differences still remained as relative exercise intensity is higher at the same velocity during exercise in hot environments (35). The confounding variables of caffeine and alcohol $(72 \mathrm{~h})$, nonsteroidal anti-inflammatory medications $(48$ h) $(48,65)$, dietary supplementation (vitamins, ergogenic aids; 30 days), exercise (7 days) (45), nonexercise-based thermal stressors (3 mo), and hypoxic and hyperbaric stressors (3 mo) were controlled for via abstinence prior to testing and throughout the testing period. A questionnaire was administered prior to each testing session and sampling time point to determine adherence to the aforementioned experimental control measures. Adherence was $100 \%$ in all participants. Participants were instructed to drink $500 \mathrm{ml}$ of water $2 \mathrm{~h}$ before each experimental trial in line with the American College of Sports Medicine position stand (55) and recent work in the field (26, 27). Hydration status was assessed via urine osmolality (UOsm). All

\section{Temperate condition $\left(20^{\circ} \mathrm{C}, 50 \% \mathrm{RH}\right)$}

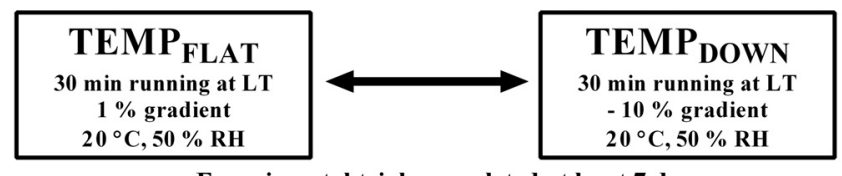

Experimental trials completed at least $7 \mathrm{~d}$ apart in a randomized counterbalanced order

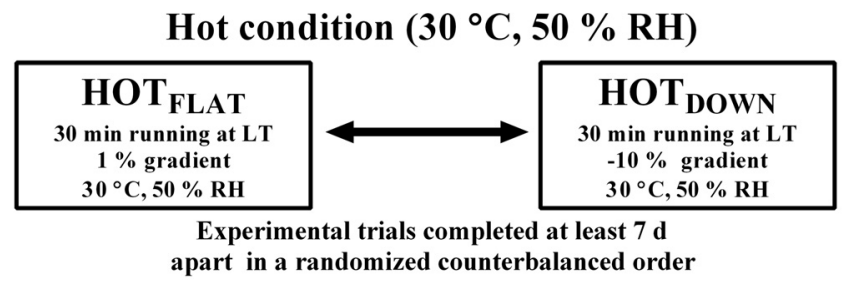

\section{Flat running interaction consists of the TEMP $P_{\mathrm{FLAT}}$ and HOT $_{\text {FLAT }}$ experimental trials}

Downhill running interaction consists of the TEMP ${ }_{\text {DOWN }}$ and HOT $_{\text {DOWN }}$ experimental trials

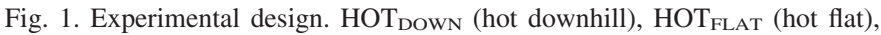
LT (lactate threshold), TEMP DOwn (temperate downhill), and TEMP FLAT (temperate flat). 
participants were euhydrated [UOsm was below 600 mosmol $/ \mathrm{kgH}_{2} \mathrm{O}$ (2)] prior to all experimental trials.

\section{Physiological Measures}

Rectal temperature $\left(\mathrm{T}_{\mathrm{re}}\right)$ was continuously measured using a rectal thermistor (Henleys 400H/4491H, Welwyn Garden City, UK) inserted $10 \mathrm{~cm}$ past the anal sphincter. The signal was amplified and measured using a temperature monitor (ET402; Libra Medical, Reading, UK). Participants were removed from the environmental chamber if exercising $\mathrm{T}_{\mathrm{re}}$ reached the ethical safety limit of $39.7^{\circ} \mathrm{C}$ or $\mathrm{T}_{\mathrm{re}}$ increased by $2^{\circ} \mathrm{C}$ from resting value, as recommended by the institutional ethical board. Heart rate was recorded continuously (Cortex Metalyser 2B, Biophysik, Leipzig, Germany) from a Polar telemetric HR monitor (attached to the chest), while ratings of perceived exertion (RPE) (9) and thermal sensation (TS) (70) were measured at rest and every 5 min during experimental trials. Pulmonary gas exchange was measured breath by breath using an online gas analysis system (Cortex Metalyser 2B; Biophysik, Leipzig, Germany) to measure changes in oxygen uptake $\left(\dot{\mathrm{V}}_{2}\right)$ and was averaged over 5 -s periods. The average of six 5 -s periods ( $30 \mathrm{~s}$ total) from $15 \mathrm{~s}$ before to $15 \mathrm{~s}$ after each time interval was taken as the oxygen uptake at that time interval. Fingertip capillary whole blood samples were obtained in duplicate before (basal) and immediately after exercise to determine B[La] (Analox, Stokesley, UK; coefficient of variation, 2.65\%).

\section{Measurements of Delayed Onset Muscle Soreness}

Noninvasive measures of DOMS were recorded immediately before (basal), immediately postexercise, $3 \mathrm{~h}$ postexercise, and $24 \mathrm{~h}$ postexercise to infer whether EIMD had occurred. Quadriceps tenderness (QT) using an analog force gauge was measured in accordance with a previously validated method (10). This method had an intratester intraclass correlation coefficient (ICC) of 0.76 (10). Sampling locations were always within the belly of each muscle as distal and proximal locations have a lower pain threshold at rest and a more variable tenderness response (5). Perceived muscle soreness was measured using the visual analog scale of pain (VAS) and was assessed along a $10-\mathrm{cm}$ scale $(0=$ no soreness, $10=$ extreme soreness). The VAS has previously been validated as a reliable measure (ICC of 0.97 ) of muscular pain (8).

\section{Molecular Physiology Measures}

Leukocyte isolation and RNA extraction. Venous blood was obtained from the antecubital region into a 6-ml EDTA tube immediately before (basal), immediately postexercise, $3 \mathrm{~h}$ postexercise, and $24 \mathrm{~h}$ postexercise. Using an adaptation of a previously validated method (62), we pipetted $500 \mu \mathrm{l}$ of venous blood into $10 \mathrm{ml}$ of 1 in 10 red blood cell lysis solution $(10 \times$ red blood cell lysis solution; Miltenyi Biotech, Surrey, UK). Samples were incubated for $15 \mathrm{~min}$ at room temperature and then isolated via centrifugation at $400 \mathrm{~g}$ for 5 min and washed twice in $2 \mathrm{ml}$ of PBS at $400 \mathrm{~g}$ for $5 \mathrm{~min}$. The TRIzol method was then used to extract RNA from the leukocytes, in accordance with manufacturer's instructions (Invitrogen; Life Technologies, Carlsbad, CA). Quantity was determined at an optical density of $260 \mathrm{~nm}$, while quality was determined via the 260/280 and
260/230 ratios using a Nanodrop spectrophotometer (Nanodrop 2000c; Thermo Scientific, Horsham, UK).

One-step RT-quantitative PCR. Primers (see Table 2) were designed using primer design software (Primer Quest and Oligoanalyzer-Integrated DNA technologies). During primer design, sequence homology searches were performed against the GenBank database to ensure the primers matched the gene of interest. Primers were designed to span exon-intron boundaries and avoided three or more guanine-cytosine bases within the last five bases at the $3^{\prime}$ end of primer to avoid nonspecific binding. Further searches were performed to ensure primers did not contain secondary structures and intermolecular or intramolecular interactions (hairpins, self-dimer, and cross dimers), which can inhibit product amplification. Relative Hsp mRNA expression was then quantified using RT-QPCR. Reactions $(20 \mu \mathrm{l})$ containing $10 \mu \mathrm{l}$ of SYBR Green RT-PCR Mastermix (Quantifast SYBR Green kit; Qiagen, Manchester, UK), $0.15 \mu \mathrm{l}$ of forward primer, $0.15 \mu$ l of reverse primer, $0.2 \mu \mathrm{l}$ of reverse transcription mix (Quantifast RT Mix, Qiagen), and $9.5 \mu$ l sample (70 ng RNA/ $\mu \mathrm{l}$ ) were prepared using the Qiagility automated pipetting system (Qiagen). Each reaction was amplified in a thermal cycler (Rotorgene Q, Qiagen) and involved reverse transcription lasting $10 \mathrm{~min}$ at $50^{\circ} \mathrm{C}$ and a transcriptase inactivation and initial denaturation phase lasting $5 \mathrm{~min}$ at $95^{\circ} \mathrm{C}$. The PCR reaction then followed with a denaturation step lasting $10 \mathrm{~s}$ at $95^{\circ} \mathrm{C}$ and a primer annealing and extension stage lasting $30 \mathrm{~s}$ at $60^{\circ} \mathrm{C}$ repeated for 40 cycles. Fluorescence was measured following each cycle as a result of the incorporation of SYBR Green dye into the amplified PCR product. Melt curves $\left(50\right.$ to $95^{\circ} \mathrm{C}$; Ramp protocol, 5-s stages) were analyzed for each reaction to ensure only the single gene of interest was amplified.

The relative quantification of mRNA expression for each sample was assessed by determining the ratio between the cycle threshold $\left(C_{T}\right)$ value of the target mRNA and the $C_{T}$ values for $\beta_{2}$-microglobulin. Fold change in relative mRNA expression was calculated using the $2-\Delta \Delta \mathrm{C}_{\mathrm{T}}$ method (57). Because HSP72 and HSP90 $\alpha$ protein concentrations were not measured and thermotolerance was not tested, the superior experimental trial to confer HSP72- and HSP90 $\alpha$-mediated thermotolerance cannot be determined. However, measurement of Hsp72 mRNA and Hsp90 $\alpha$ mRNA responses provides an indication that the heat shock response has been activated and, therefore, suggests the experimental trial most likely to confer HSP72- and HSP90 $\alpha$-mediated thermotolerance.

\section{Statistical Analysis}

Central tendency and dispersion are reported as the mean and standard deviation for normally distributed data and as the median and interquartile range for nonnormally distributed data. Statistical analysis was completed using linear mixed models for repeated measures (IBM SPSS 19.0, Chicago, IL). The best fitting covariance structure was identified by minimizing the Hurvich and Tsai's criterion (20). Changes in Hsp72 and Hsp90 $\alpha$ mRNA are presented as a fold change from basal in accordance with previous literature (52). Where significant $F$ ratios for main and interaction effects occurred, post hoc comparisons were made with Bonferroni-adjusted $P$ values. Pearson correlation coefficients were determined to elucidate relationships

Table 2. Primer Sequences

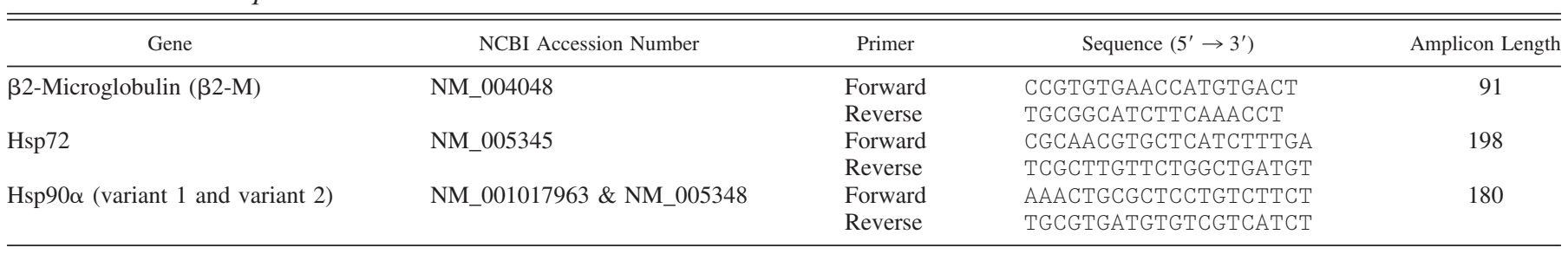

NCBI, National Center for Biotechnology Information. 


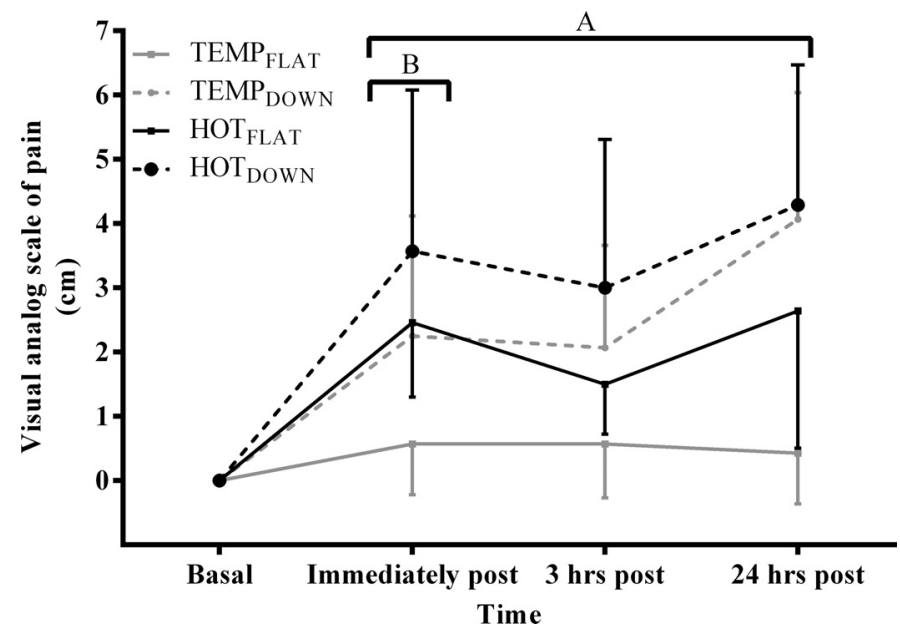

Fig. 2. Perceived muscle soreness (visual analog scale of pain, VAS) mean \pm SD immediately before, immediately postexercise, $3 \mathrm{~h}$ postexercise, and $24 \mathrm{~h}$ postexercise. ${ }^{\mathrm{A}} \mathrm{VAS}$ increased significantly $(P<0.005)$ during downhill running compared with flat running. ${ }^{\mathrm{B}}$ VAS increased significantly $(P<0.001)$ in hot compared with temperate conditions.

between exercising $\mathrm{T}_{\mathrm{re}}$, VAS, QT, Hsp72, and Hsp90 $\alpha$ mRNA. Correlation strength was determined via Cohen's threshold (11). Statistical significance was accepted at $P<0.05$ (two-tailed).

\section{RESULTS}

\section{Perceived Muscle Soreness Response}

VAS (Fig. 2) increased following downhill running immediately after exercise, $3 \mathrm{~h}$ postexercise, as well as $24 \mathrm{~h}$ postexercise $(P<0.001)$, and during flat running immediately postexercise and $24 \mathrm{~h}$ postexercise $(P<0.006)$ compared with basal. Increased VAS was observed following downhill running compared with flat running immediately postexercise, $3 \mathrm{~h}$ postexercise, and $24 \mathrm{~h}$ postexercise $(P<0.005)$. Increased VAS was also observed following hot $(P<0.001)$ and temperate $(P<0.016)$ conditions immediately postexercise, $3 \mathrm{~h}$ postexercise, and $24 \mathrm{~h}$ postexercise compared with basal and in hot compared with temperate conditions immediately postexercise $(F=6.2 ; P=0.020)$. The interaction between environmental condition, treadmill gradient, and time had no effect on VAS $(P>0.05)$. Therefore, both downhill running and hot conditions increased VAS, with downhill running appearing to cause the largest increase.

Like VAS, quadriceps tenderness (QT; Fig. 3) increased during downhill running at $3 \mathrm{~h}(P=0.001)$ and $24 \mathrm{~h}$ postexercise $(P<0.002)$ compared with basal. However, during flat running, QT only increased $24 \mathrm{~h}$ postexercise $(P=0.010)$ compared with basal. Environmental temperature and all other interactions had no effect on QT $(P>0.05)$. Therefore, downhill running was the main factor that induced QT.

\section{Physiological Responses}

Exercising $\mathrm{T}_{\text {re }}$ (Fig. 4) increased during downhill running compared with flat running between 10 and $30 \mathrm{~min}(P<$ 0.006). There was also a trend for exercising $\mathrm{T}_{\mathrm{re}}$ to be increased in hot $\left(38.9 \pm 0.4^{\circ} \mathrm{C}\right)$ compared with temperate conditions $\left(38.6 \pm 0.5^{\circ} \mathrm{C}\right)$ at $30 \mathrm{~min}(F=4.0 ; P=0.068)$. Increases at 30 min during downhill running $\left(39.0 \pm 0.4^{\circ} \mathrm{C}\right)$ compared with flat running $\left(38.5 \pm 0.4^{\circ} \mathrm{C} ; 0.5^{\circ} \mathrm{C}\right)$ were

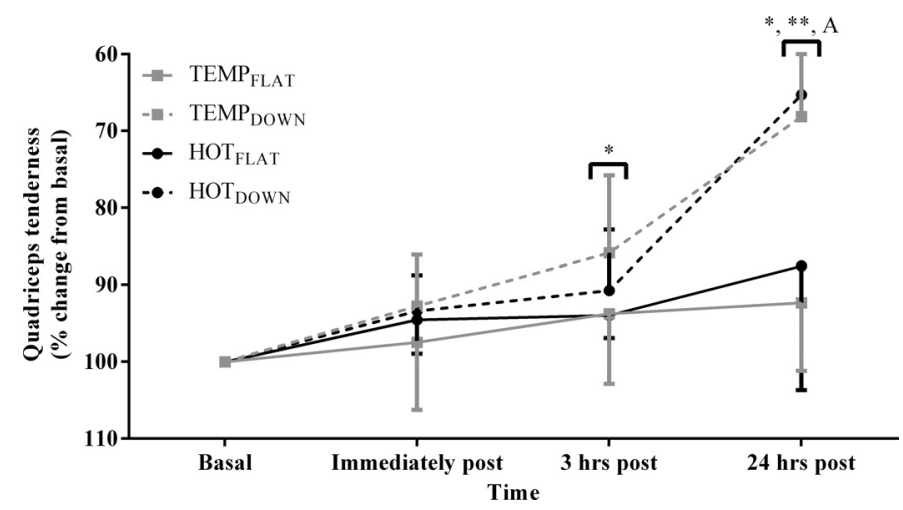

Fig. 3. Quadriceps tenderness (QT) means \pm SD immediately before, immediately postexercise, $3 \mathrm{~h}$ postexercise, and $24 \mathrm{~h}$ postexercise. ${ }^{*} \mathrm{QT}$ increased significantly $(P=0.010)$ during flat running compared with basal. **QT increased significantly $(P<0.002)$ during downhill running compared with basal. ${ }^{\mathrm{A}} \mathrm{QT}$ increased significantly $(P<0.001)$ during downhill running compared with flat running.

greater than during hot compared with temperate environmental conditions $\left(0.3^{\circ} \mathrm{C}\right)$, indicating downhill running had a greater effect on exercising $\mathrm{T}_{\mathrm{re}}$ than hot environmental temperatures. Exercising $\mathrm{T}_{\mathrm{re}}\left(39.2 \pm 0.2^{\circ} \mathrm{C}\right)$ increased at 30 min of HOT $_{\text {DOWN }}$; however, the interaction between environmental condition, treadmill gradient, and time did not reach significance $(P>0.05)$. Heart rate (Table 3$)$ increased over time $(F=318.0 ; P<0.001)$. No other main effect or interaction reached significance $(P>0.05)$, indicating $\mathrm{HR}$ did not differ between treadmill gradients or environmental conditions; however, there was a tendency $(F=4.3 ; P=$ 0.056) for $\mathrm{HR}$ to be increased during hot (162 \pm 36 beats $\left.\cdot \mathrm{min}^{-1}\right)$ compared with temperate conditions (153 \pm 33 beats $\left.\cdot \min ^{-1}\right)$.

Oxygen uptake $(F=7.4 ; P<0.001$; Table 3$)$ and $\mathrm{B}[\mathrm{La}]$ ( $F=30.0 ; P<0.001$; Table 3 ) increased over time; however, no other main effect or interaction reached significance $(P>$ 0.05). Participants exercised at an average $\% \dot{\mathrm{V}}_{2 \max }$ of $76.0 \pm$ $6.4 \%$ during temperate flat trials, $76.1 \pm 9.0 \%$ during temperate downhill trials, $76.3 \pm 4.2 \%$ during hot flat trials, and $76.5 \pm 5.1 \%$ during hot downhill trials.

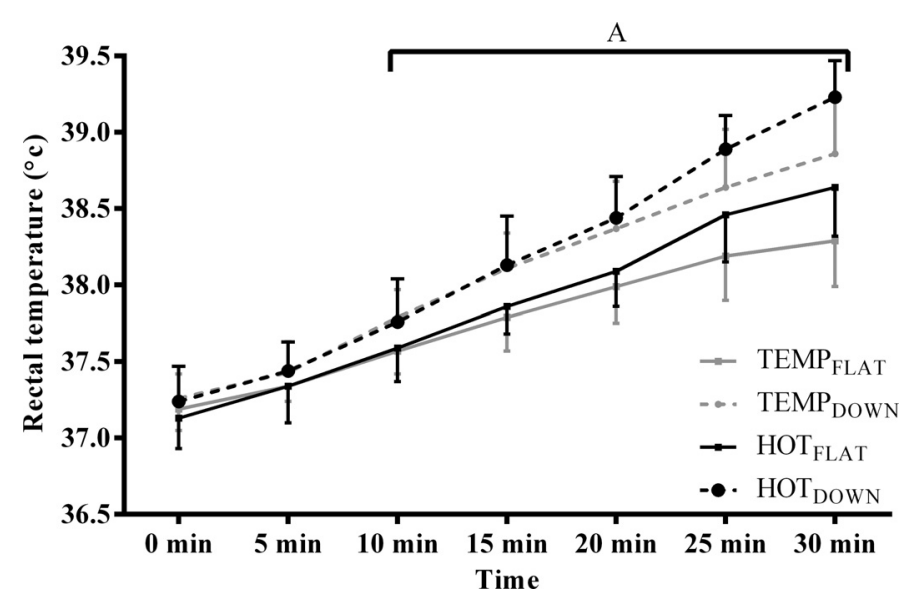

Fig. 4. Rectal temperature $\left(\mathrm{T}_{\mathrm{re}}\right)$ means $\pm \mathrm{SD}$ during each experimental trial. ${ }^{\mathrm{A}} \mathrm{T}_{\mathrm{re}}$ increased significantly $(P<0.010)$ during downhill running compared with flat running. 
Table 3. Physiological and perceptual responses

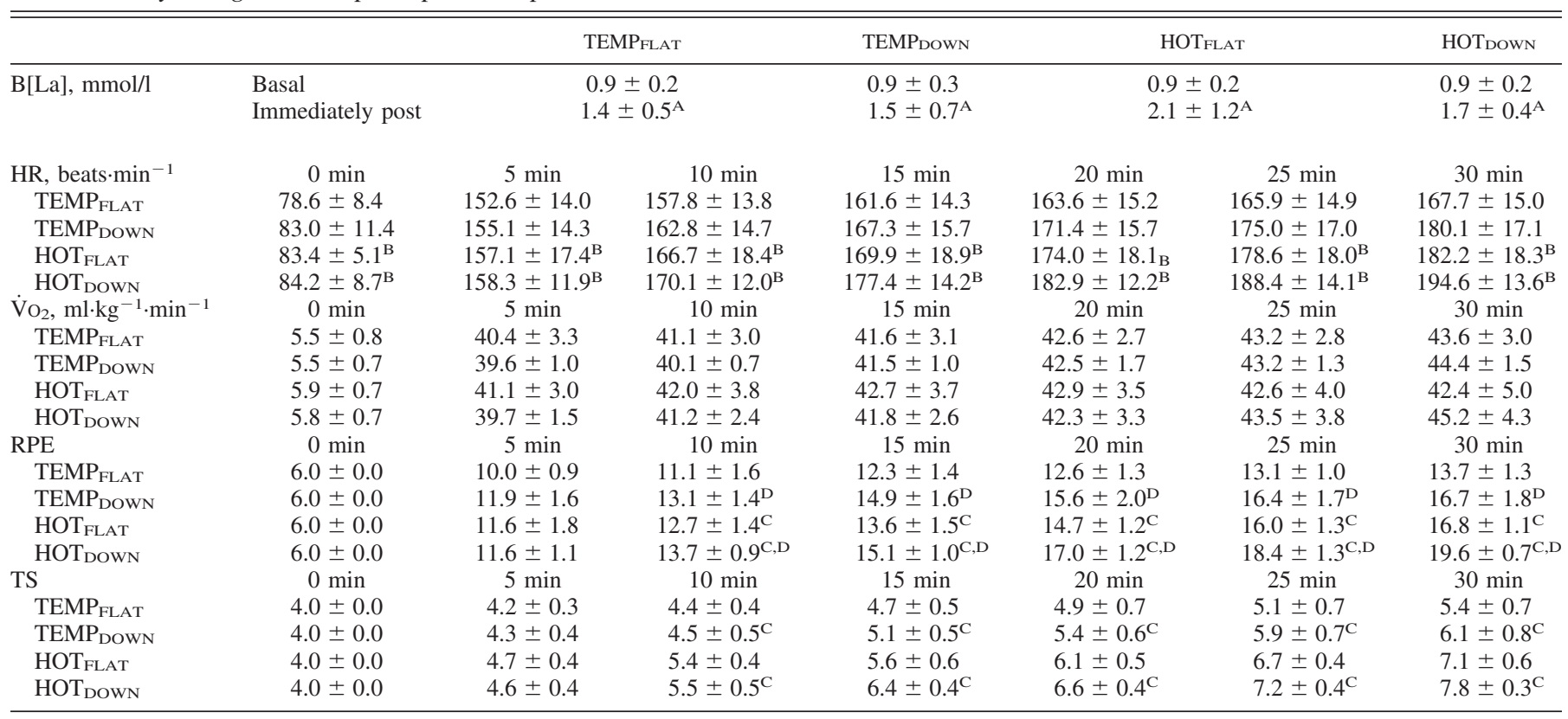

Values are expressed as means $\pm \mathrm{SD}$. ${ }^{\mathrm{A}}$ Increased immediately post compared to basal as a main effect. ${ }^{\mathrm{B}}$ Trend to increase in hot compared to temperate conditions; $P=0.056$ ). ${ }^{C}$ Increased in hot compared to temperate conditions between 10-30 min; $P<0.05$. ${ }^{\mathrm{D}}$ Increased during downhill running compared to flat running between $10-30 \mathrm{~min} ; P<0.05$.

\section{Perceptual Response}

Rate of perceived exertion (Table 3) increased during hot compared with temperate conditions $(F=12.3 ; P=0.002)$, in downhill running compared with flat running $(F=34.8 ; P<$ $0.001)$, and over time $(F=171.6 ; P<0.001)$. RPE also increased in hot compared with temperate conditions at $10 \mathrm{~min}$ $(P=0.045)$, between 20 and $30 \mathrm{~min}(P<0.002)$, and during downhill running compared with flat running at $10 \mathrm{~min}(P=$ $0.003)$ and between 15 and 30 min $(P<0.001)$.

Thermal sensation (Table 3 ) increased during hot compared with temperate conditions ( $F=45.1 ; P<0.001)$, in downhill running compared with flat running $(F=9.0 ; P=0.004)$, and over time $(F=95.1 ; P<0.001)$ as main effects. Thermal sensation also increased within hot compared with temperate conditions between $10 \mathrm{~min}$ and $30 \mathrm{~min}$ of exercise $(P<0.001)$. However, no other interactions had any effect on RPE or TS $(P>0.05)$. Therefore, both RPE and TS were greater during downhill running and within hot conditions.

\section{Leukocyte Hsp72 mRNA and Hsp90a mRNA Responses}

Leukocyte Hsp72 mRNA (Fig. 5) increased over time with increases observed immediately postexercise and $3 \mathrm{~h}$ postexercise $(P<0.001)$. Leukocyte Hsp72 mRNA also increased following downhill running $(P<0.002)$, flat running $(P<$ $0.015)$, and within hot $(P<0.001)$ and temperate environmental conditions $(P<0.020)$ immediately postexercise and $3 \mathrm{~h}$ postexercise compared with basal. These leukocyte Hsp72 mRNA increases were greater following downhill running (1.9 \pm 0.9 -fold) compared with flat running (1.3 \pm 0.4 -fold; $F=$ $15.2, P=0.001)$ and in hot $(1.9 \pm 0.6$-fold $)$ compared with temperate $(1.1 \pm 0.5$-fold $)$ environmental conditions $(F=$ $11.7 ; P=0.003)$ immediately postexercise. Leukocyte Hsp72 mRNA returned to basal levels at $24 \mathrm{~h}(P>0.05)$. Therefore, downhill running and hot environmental conditions were the best stimuli to induce leukocyte Hsp72 mRNA. Leukocyte Hsp72 mRNA increased immediately post HOT $_{\text {DOwN }}(0.8 \pm$ 0.2 -fold to $2.1 \pm 1.2$-fold); however, the interaction between environmental condition, treadmill gradient, and time did not reach significance $(P>0.05)$. Significant correlations were observed between Hsp72 mRNA and peak exercising $\mathrm{T}_{\mathrm{re}}(r=$ $0.625 ; P<0.001$, large $)$, VAS $(r=0.402 ; P=0.042$, moderate) and QT ( $r=0.436 ; P=0.026$, moderate). This suggests that exercising $\mathrm{T}_{\mathrm{re}}$ and DOMS may have a role in the Hsp72 mRNA increases observed.

Leukocyte Hsp90 $\alpha$ mRNA (Fig. 6) increased following downhill running $(P<0.002)$ and in hot conditions $(P<$ $0.006)$ immediately postexercise and $3 \mathrm{~h}$ postexercise compared with basal. Leukocyte Hsp $90 \alpha$ mRNA also increased immediately postexercise following flat running $(P=0.008)$ and in temperate conditions $(P=0.049)$. Leukocyte Hsp90 $\alpha$ mRNA increases were greater following downhill running $(1.4 \pm 0.8$-fold $)$ compared with flat running immediately postexercise $(0.9 \pm 0.6$-fold; $F=13.2 ; P=0.002), 3 \mathrm{~h}$ postexercise $(F=6.0 ; P=0.025)$, and $24 \mathrm{~h}$ postexercise $(F=$ 6.7; $P=0.019)$. Leukocyte Hsp90 $\alpha$ mRNA also increased immediately postexercise within hot $(1.6 \pm 1.0$-fold $)$ compared with temperate $(0.9 \pm 0.6$-fold $)$ conditions $(F=12.4 ; P=$ $0.003)$. Therefore, downhill running and hot conditions were the best stimuli to induce leukocyte Hsp90 $\alpha$ mRNA. Leukocyte $\mathrm{Hsp} 90 \alpha$ mRNA increased following HOT $_{\text {DOwN }}(0.7 \pm$ 0.2 -fold to $1.7 \pm 1.0$-fold); however, the interaction between environmental condition, treadmill gradient, and time did not reach significance $(P>0.05)$. Significant correlations were observed between Hsp90 $\alpha$ mRNA and peak exercising $\mathrm{T}_{\mathrm{re}}$ $(r=0.706 ; P<0.001$, large), VAS $(r=0.453 ; P=0.02$, moderate), and QT $(r=0.436 ; P=0.026$, moderate). This 
A
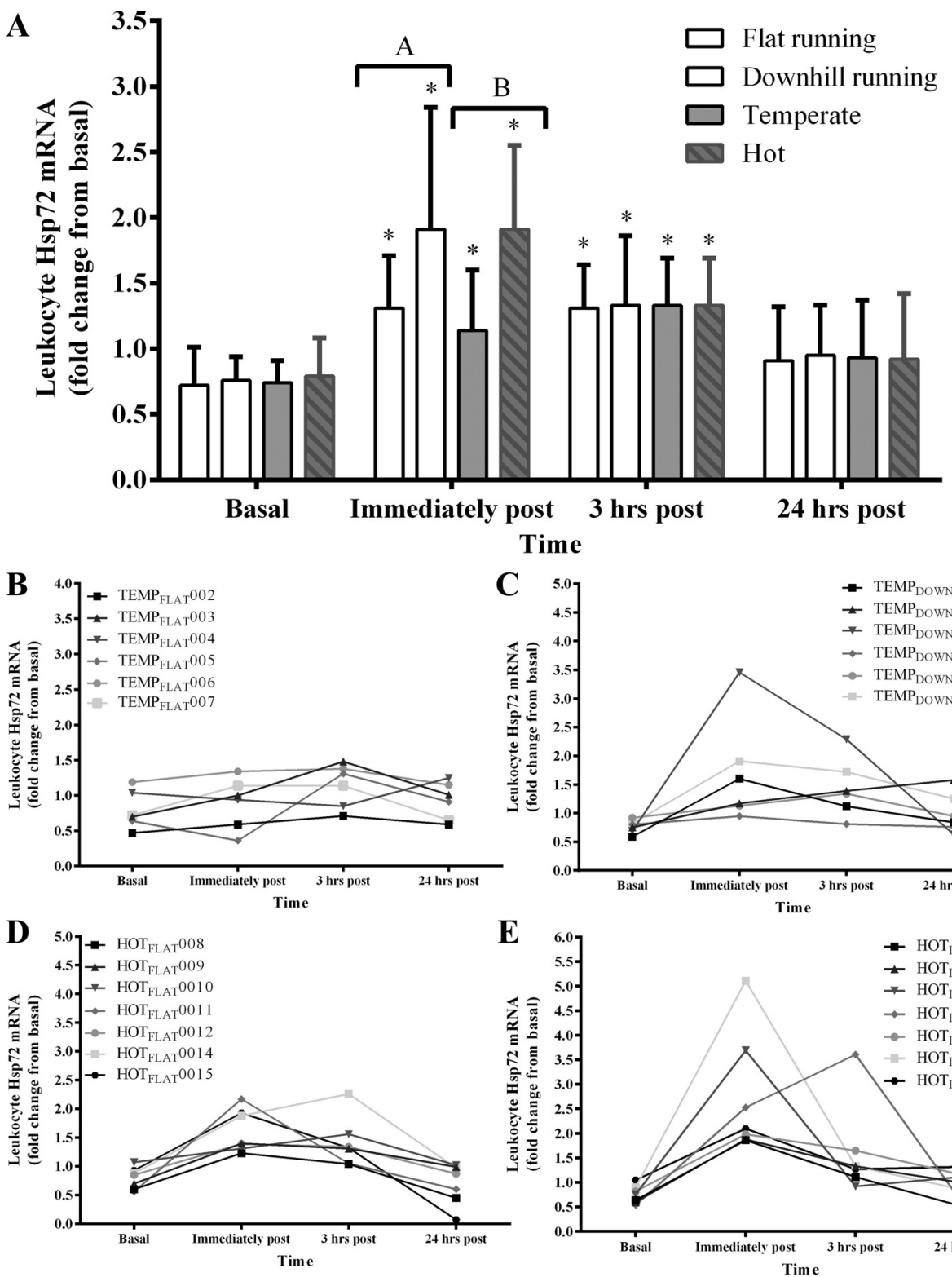

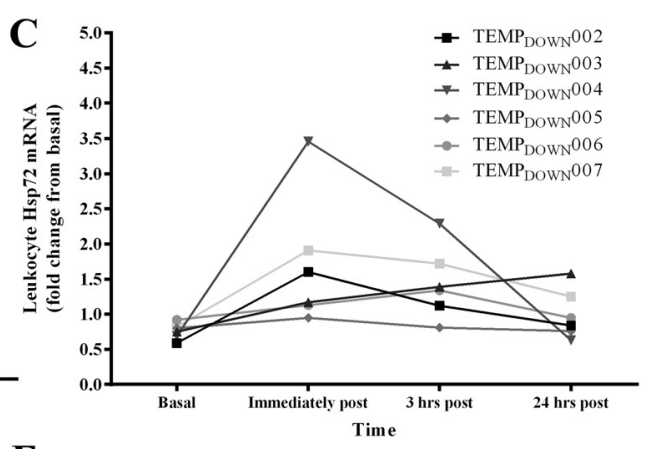

$\mathbf{E}$

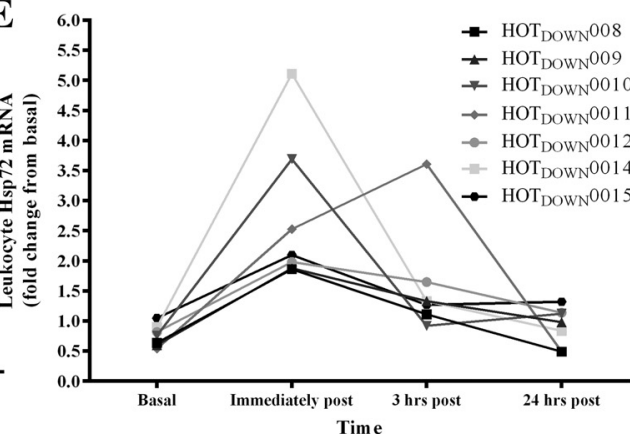

Fig. 5. A: leukocyte Hsp72 mRNA median \pm interquartile range immediately before exercise, immediately postexercise, and 3 and 24 $\mathrm{h}$ postexercise. Data pooled to enable comparisons between all individuals who exercised in temperate conditions to those who exercised in hot conditions, and between all individuals who completed flat running trials to those who completed downhill running trials (i.e., comparison of main effects). $B$ : individual leukocyte Hsp72 mRNA response to temperate flat $\left(20^{\circ} \mathrm{C}, 50 \% \mathrm{RH}, 1 \%\right.$ gradient), $C$ : temperate downhill $\left(20^{\circ} \mathrm{C}, 50 \% \mathrm{RH}\right.$, $-10 \%$ gradient $), D$ : hot flat $\left(30^{\circ} \mathrm{C}, 50 \% \mathrm{RH}\right.$, $1 \%$ gradient $), E$ : hot downhill $\left(30^{\circ} \mathrm{C}, 50 \%\right.$ $\mathrm{RH},-10 \%$ gradient). Data are presented as fold change from basal. *Significant increase compared with basal $(P<0.05)$. ${ }^{\text {A Signifi- }}$ cant increase $(P=0.001)$ during downhill running compared with flat running. ${ }^{B} \mathrm{Sig}$ nificant increase $(P=0.003)$ in hot group compared with the temperate group. suggests exercising $\mathrm{T}_{\mathrm{re}}$ and DOMS may have a role in the Hsp90 $\alpha$ mRNA increases observed.

\section{DISCUSSION}

The current study demonstrated that observed increases in Hsp72 and Hsp90 $\alpha$ mRNA were treadmill gradient and environmental temperature-dependent with downhill running and hot conditions being the biggest stimuli.

\section{Leukocyte Hsp72 mRNA}

Exercising $\mathrm{T}_{\mathrm{re}}$ increased during downhill running compared with flat running and showed a trend to be increased within hot compared with temperate conditions. Further, a significant positive correlation was observed between peak exercising $\mathrm{T}_{\mathrm{re}}$ and Hsp72 mRNA immediately postexercise, suggesting exercising $\mathrm{T}_{\mathrm{re}}$ increases were an important stimuli for Hsp72 mRNA induction. This is in agreement with previous literature in which an elevated exercising $\mathrm{T}_{\mathrm{re}}$ led to increased Hsp72
mRNA transcription within peripheral blood mononuclear cells (PBMCs) $(18,38)$ and lymphocytes $(40)$, probably via increased protein denaturation (40), activating heat shock factor-1 (HSF-1) (49). Activation of a distinct immune response by each leukocyte subset occurs following exercise and exercise heat stress via the release of factors into the systemic circulation (67-68). This immune response includes activation of an oxidative burst within neutrophils via stimulation by ligands, including extracellular HSP72 and noradrenaline (24). Increased oxidative stress has also been observed within lymphocytes $(40,60)$ following exercise. These prooxidant events could increase protein denaturation-activating transcription of Hsp72 and Hsp90 $\alpha$ mRNA. Caution should be taken with these conclusions, as other studies demonstrate an attenuated oxidative stress response within neutrophils (53) and monocytes (42) following highintensity exercise (53), likely via the effects of large adrenaline (64) and cortisol (50) increases. 
Fig. 6. A: leukocyte Hsp90 $\alpha$ mRNA median \pm interquartile range immediately before exercise, immediately postexercise, and 3 and $24 \mathrm{~h}$ postexercise. Data pooled to enable comparisons between all individuals who exercised in temperate conditions to those who exercised in hot conditions, and between all individuals who completed flat running trials to those who completed downhill running trials (i.e., comparison of main effects). $B$ : individual leukocyte $\mathrm{Hsp} 90 \alpha$ mRNA response to temperate flat $\left(20^{\circ} \mathrm{C}, 50 \% \mathrm{RH}, 1 \%\right.$ gradient). $C$ : temperate downhill $\left(20^{\circ} \mathrm{C}, 50 \%\right.$ $\mathrm{RH},-10 \%$ gradient). $D$ : hot flat $\left(30^{\circ} \mathrm{C}, 50 \%\right.$ $\mathrm{RH}, 1 \%$ gradient). $E$ : hot downhill $\left(30^{\circ} \mathrm{C}\right.$, $50 \% \mathrm{RH},-10 \%$ gradient). Data are presented as fold change from basal. *Significant increase $(P<0.05)$ from basal. ${ }^{\text {A }}$ Significant increase $(P<0.05)$ during downhill running compared with flat running. ${ }^{\mathrm{B}} \mathrm{Sig}-$ nificant increase $(P<0.05)$ within hot compared with temperate conditions.
A
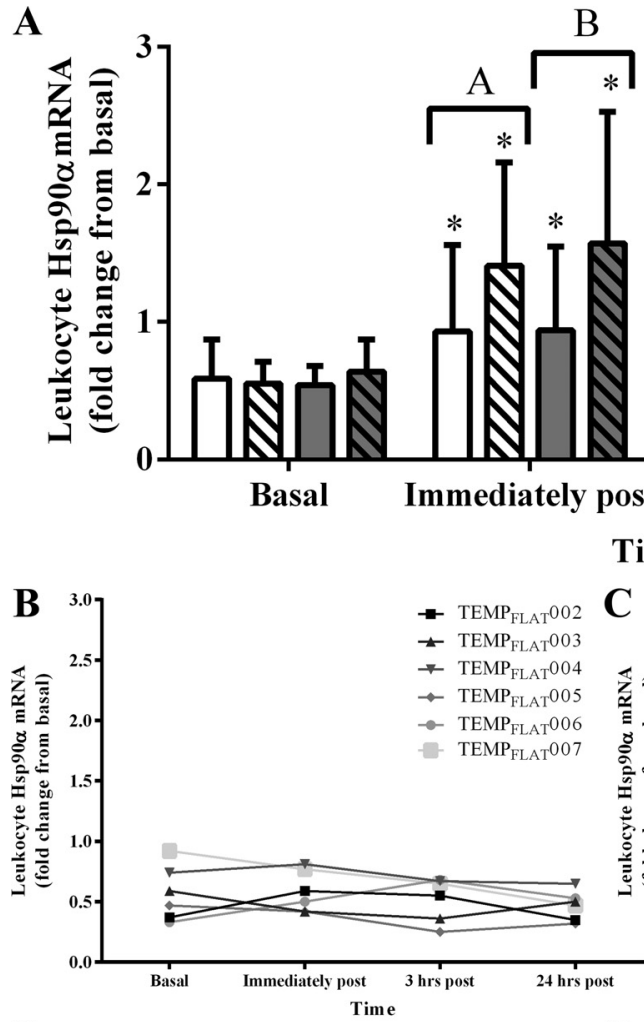

D

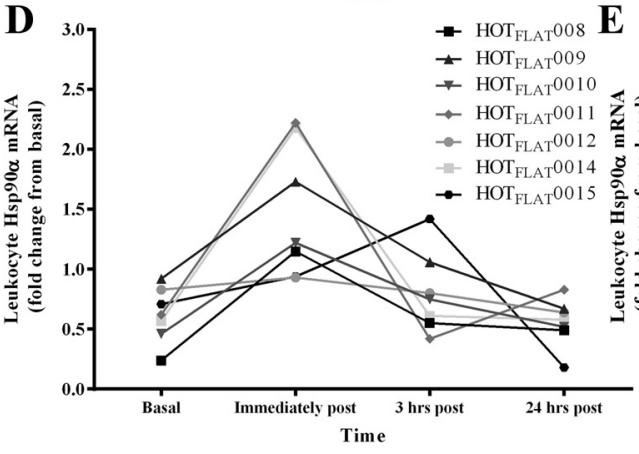

$\mathrm{B}$

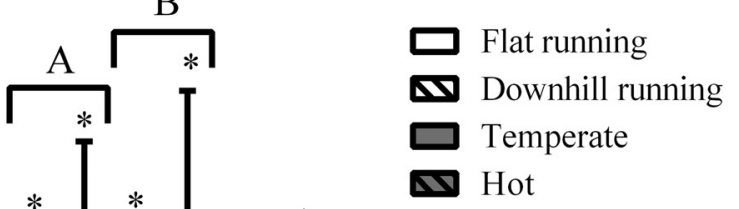

Hot

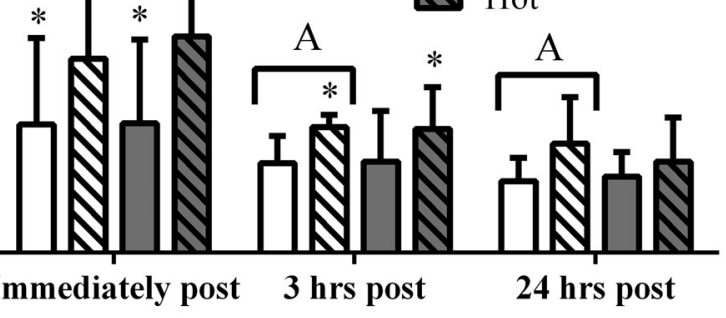

Time
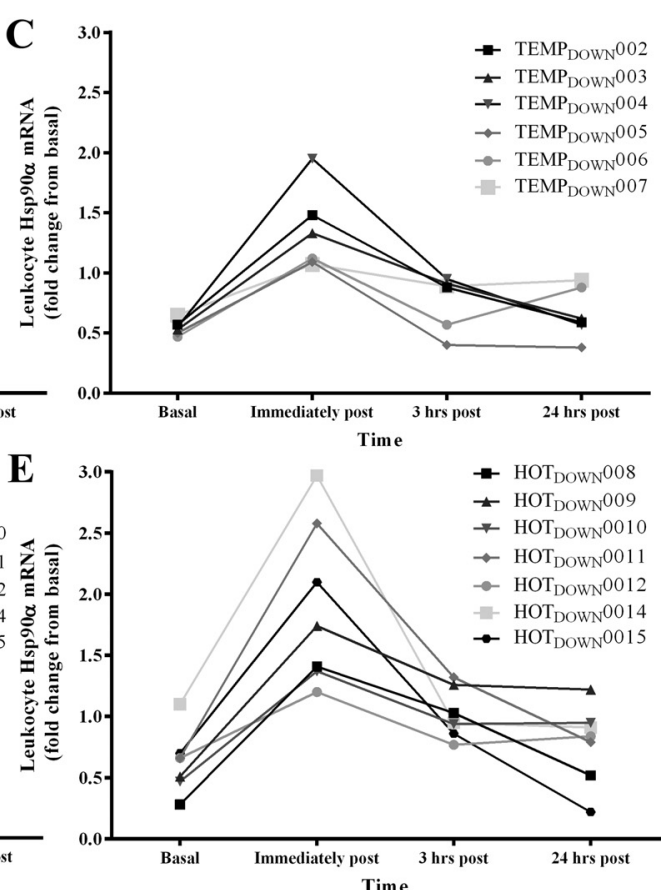

During downhill running, DOMS was increased, suggesting EIMD was present (23). Muscle damage induced following isokinetic eccentric contractions (52) and downhill running (63) increases Hsp72 mRNA postexercise within the human vastus lateralis (VL). This increase is greater during muscle damaging eccentrically biased exercise compared with nondamaging concentrically biased exercise (66). Despite characterization of the Hsp72 mRNA response to EIMD in the VL, no data exist on the Hsp72 mRNA response within leukocytes. Further, the precise mechanism linking EIMD and leukocyte Hsp72 mRNA is unclear. A Toll-like receptor 4 (TLR4)mediated cellular stress response occurs within leukocytes following muscle-damaging exercise (19). Signaling pathways induced by TLR activation increase oxidative stress via NADPH oxidase activation (4), increasing protein denaturation and activation of JNK and p38 MAPK signaling (28). These changes are known to induce Hsp72 mRNA transcription via HSF-1 activation. Damage-associated molecular patterns (DAMPs), including extracellular HSPs, endogenous nucleic acids, circulating cell-free DNA, high-mobility group box -1 and liposaccharide activate this TLR-mediated leukocyte stress response $(25,29,47)$. However, little evidence exists for DAMPs being released from skeletal muscle following muscle damage in humans. IL-6 infusion increases Hsp72 mRNA in the VL at rest (16). Whether IL-6 has the same effect on leukocytes following exercise heat stress has not been established. Further, IL-6 is only released from skeletal muscle after $120 \mathrm{~min}$ of exercise (59). Therefore, it is unlikely that factors released from skeletal muscle following muscle damage induced Hsp72 mRNA within the current study design. A higher rate of ATP breakdown occurs when exercise of the same steady-state velocity is completed within a hot environment compared with the same trial within a temperate environment (15). Therefore, a higher relative exercise intensity is required to sustain the same running velocity in hot conditions. Consequently, this increased metabolic strain could partially account for Hsp72 mRNA increases within hot environmental conditions as the HSP72 protein response is intensity-dependent both within skeletal muscle (34) and leukocytes (38). This is not surprising as protein denaturation, the key cellular change driving Hsp72 mRNA transcription, is exercise intensity (31) and metabolic strain-dependent (7). 
Although the current study demonstrated that Hsp72 mRNA increases following downhill running and exercise within a hot environment, the combination of the two stressors HOT $_{\text {DOwN }}$ did not induce any further increases. Upregulation of Hsp72 mRNA appears to be largely exercising $\mathrm{T}_{\mathrm{re}}$-dependent within the current study design. However, exercising $\mathrm{T}_{\mathrm{re}}$ did not increase any further during $\mathrm{HOT}_{\mathrm{DOwN}}$ and, therefore, the lack of any additional physiological stimuli could partially explain the observed responses. The variability of the individual Hsp72 mRNA responses could also explain why a significant increase was not found. Indeed, despite Hsp72 mRNA increasing within all participants who completed downhill running and exercise in hot environments, these increases were highly variable (0.2-4.2 fold). Typically, the HSP72 response to exercise is highly variable (45). However, the use of two experimental groups would have compounded this variability (36) due to the different thermoregulatory and metabolic responses between individuals.

Previous research demonstrated that HSP72 increases were sustained for $24 \mathrm{~h}$ following exercise heat stress despite Hsp72 mRNA expression returning to baseline (18). Therefore, both downhill running and exercise in a hot environment could elevate basal HSP72 concentrations for up to $24 \mathrm{~h}$ postexercise. However, the current study cannot suggest that downhill running or exercise in hot environments can translate this signal into HSP72-mediated thermotolerance within leukocytes because increased Hsp72 mRNA expression is not necessarily reflective of functional steady-state $\operatorname{HSP} 72$ content $(38,66)$. Any HSP72 increases that were potentially induced by downhill running or exercise in a hot environment would not have had a confounding effect on the Hsp72 and Hsp90 $\alpha$ mRNA responses, as HSP72 increases are sustained for less than 7 days within leukocyte subsets (monocytes) $(18,32)$.

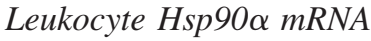

Previously, investigation of the Hsp90 $\alpha$ mRNA response within humans was limited; however, increases were demonstrated following exercise (12) and exercise heat stress (44) within PBMCs and lymphocytes, respectively. As these responses were measured in isolation and the response following EIMD is absent from the literature, the best singular stressor or combination of exercise-related stressors to increase Hsp90 $\alpha$ mRNA was unclear. The current study demonstrated that downhill running and hot conditions offered the largest stimuli for increasing Hsp90 $\alpha$ mRNA. Induction of Hsp90 $\alpha$ mRNA was correlated with exercising $\mathrm{T}_{\mathrm{re}}$ and DOMS; however, as previously discussed for Hsp72 mRNA, it is difficult to mechanistically link EIMD and the leukocyte stress response. Therefore, Hsp90 $\alpha$ mRNA increases are likely exercising $\mathrm{T}_{\mathrm{re}}$-dependent. The increased metabolic strain during exercise in hot environments and the exercise-mediated activation of the innate immune response also likely play a role. Further investigation is required to elucidate whether Hsp $90 \alpha$ mRNA needs to remain elevated to sustain increased basal HSP90 $\alpha$ concentrations and whether these increases mediate conferred thermotolerance.

\section{Practical Applications and Future Directions}

Exercise heat stress and downhill running demonstrated similar magnitude Hsp72 and Hsp90 $\alpha$ mRNA increases with no additive effect of combining the two stressors $\left(\mathrm{HOT}_{\mathrm{DOwN}}\right)$ observed. However, downhill running is accompanied by the negative effects of DOMS and EIMD on thermoregulation (21, 43) and exercise performance (37), which may persist for up to $24 \mathrm{~h}$ and 7 days, respectively. This is important as leukocyte HSP72 protein concentrations appear to return to basal levels within $48 \mathrm{~h}$ postexercise (18). Consequently, exercise heat stress still appears to be the superior intervention (of those tested within the current experimental design) to increase Hsp72 and Hsp90 $\alpha$ mRNA, at least within leukocytes and, therefore, potentially confer HSP72- and HSP90 $\alpha$-mediated thermotolerance (39). Induction of HSP72 protein also occurs within monocytes following exercise within an hypoxic environment (32). Future studies are required to assess whether exercise heat stress and hypoxia (singularly and in combination) are the superior intervention to induce HSP72 and HSP90 $\alpha$ within an experimental design, where metabolic strain is controlled more precisely. This would provide a better understanding of the acute intervention most suited to enhancing HSP72- and HSP90 $\alpha$-mediated thermotolerance within leukocytes. Consideration of the HSP72 and HSP90 $\alpha$ responses within skeletal muscle is also warranted due to the role of this tissue within exertional heat illness pathophysiology (56). Skeletal muscle HSP72 is induced when exercise is completed in a glycogen-depleted state (17) and following muscle-damaging exercise (52). These stressors should be tested along with exercise heat stress and exercise within hypoxic conditions. Future studies should also consider measuring whether the leukocyte Hsp72 and Hsp90 $\alpha$ mRNA responses are a valid surrogate measure for other more relevant tissues, such as skeletal muscle.

\section{Summary and Conclusions}

The current study demonstrated for the first time that leukocyte Hsp72 and Hsp90 $\alpha$ mRNA increases were treadmill gradient- and environmental temperature-dependent with downhill running and hot environmental conditions being the biggest stimuli. Exercising $\mathrm{T}_{\mathrm{re}}$ appeared to be the major physiological stimuli with increased metabolic strain during hot conditions and activation of the innate immune response potentially also contributing. As downhill running was accompanied by DOMS, exercise heat stress is the most practical stressor (of those tested) to induce Hsp72 and Hsp90 $\alpha$ mRNA within leukocytes.

\section{ACKNOWLEDGMENTS}

The authors would like to thank the participants in this study.

\section{DISCLOSURES}

No conflicts of interest, financial or otherwise, are declared by the authors.

\section{AUTHOR CONTRIBUTIONS}

Author contributions: J.A.T., P.C.C., L.T., and M.P.L. conception and design of research; J.A.T. and A.J.M. performed experiments; J.A.T., P.C.C., A.W.M., L.T., and M.P.L. analyzed data; J.A.T., P.C.C., L.T., and M.P.L. interpreted results of experiments; J.A.T. prepared figures; J.A.T. drafted manuscript; J.A.T., P.C.C., A.J.M., A.W.M., L.T., and M.P.L. edited and revised manuscript; J.A.T., P.C.C., A.J.M., A.W.M., L.T., and M.P.L. approved final version of manuscript. 


\section{REFERENCES}

1. Amorim F, Moseley PL. Heat shock protein and inflammation In: Heat Shock Proteins and Whole Body Physiology, edited by Asea A and Pedersen BK. London: Springer, 2012, p. 57-84.

2. Armstrong LE, Maresh CM, Castellani JW, Bergeron MF, Kenefick RW, Lagasse KE, Riebe D. Urinary indexes of hydration status. Int $J$ Sport Nutr 4: 265-279, 1994.

3. Arya R, Mallik M, Lakhotia SC. Heat shock genes-integrating cell survival and death. J Biosci 32: 595-610, 2007.

4. Asehnoune K, Strassheim D, Mitra S, Kim JY, Abraham E. Involvement of reactive oxygen species in Toll-like receptor 4-dependent activation of NF-кB. J Immunol 172: 2522-2529, 2004.

5. Baker SJ, Kelly NM, Eston RG. Pressure pain tolerance at different sites on the quadriceps femoris prior to and following eccentric exercise. Eur $J$ Pain 1: 229-233, 1997.

6. Baldwin J, Snow RJ, Febbraio MA. Effect of training status and relative exercise intensity on physiological responses in men. Med Sci Sport Exerc 32: $1648-1654,2000$.

7. Beckmann RP, Lovett M, Welch WJ. Examining the function and regulation of HSP-70 in cells subjected to metabolic stress. J Cell Biol 117: 1137-1150, 1992.

8. Bijur PE, Silver W, Gallagher EJ. Reliability of the visual analog scale for measurement of acute pain. Acad Emerg Med 8: 1153-1157, 2001.

9. Borg G. Perceived exertion as an indicator of somatic stress. Scand $J$ Rehabil Med 2: 92-98, 1970.

10. Cleary MA, Sitler MR, Kendrick ZV. Dehydration and symptoms of delayed-onset muscle soreness in normothermic men. J Athl Train 41: 36-45, 2006.

11. Cohen J. Statistical Power Analysis for the Behavioral Sciences. Mahwah, New Jersey: Lawrence Erlbaum, 1988.

12. Connolly PH, Caiozzo VJ, Zaldivar F, Nemet D, Larson J, Hung SP, Heck JD, Hatfield W, Cooper DM. Effects of exercise on gene expression in human peripheral blood mononuclear cells. J Appl Physiol 97: 1461-1469, 2004.

13. Epstein Y, Druyan A, Heled Y. Heat injury prevention-a military perspective. J Strength Cond Res 26: S82-S86, 2012.

14. Feasson L, Stockholm D, Freyssenet D, Richard I, Duguez S, Beckmann JS, Denis C. Molecular adaptations of neuromuscular disease-associated proteins in response to eccentric exercise in human skeletal muscle. J Physiol 543: 297-306, 2002.

15. Febbraio MA, Carey MF, Snow RJ, Stathis CG, Hargreaves M. Influence of elevated muscle temperature on metabolism during intense, dynamic exercise. Am J Physiol Regul Integr Comp Physiol 271: R1251R1255, 1996.

16. Febbraio MA, Ott P, Nielsen HB, Steensberg A, Keller C, Krustrup P, Secher NH, Pedersen BK. Exercise induces hepatosplanchnic release of heat shock protein 72 in humans. J Physiol 544: 957-962, 2002.

17. Febbraio MA, Steensberg A, Walsh R, Koukoulas I, van Hall G, Saltin B, Pedersen BK. Reduced glycogen availability is associated with an elevation in HSP72 in contracting human skeletal muscle. $J$ Physiol 538: 911-917, 2002.

18. Fehrenbach E, Niess AM, Veith R, Dickhuth HH, Northoff H. Changes of HSP72-expression in leukocytes are associated with adaptation to exercise under conditions of high environmental temperature. J Leukoc Biol 69: 747-754, 2001.

19. Fernandez-Gonzalo R, De Paz JA, Rodriguez-Miguelez P, Cuevas MJ, González-Gallego J. Effects of eccentric exercise on Toll-like receptor 4 signaling pathway in peripheral blood mononuclear cells. J Appl Physiol 112: 2011-2018, 2012.

20. Field A. Discovering Statistics Using SPSS. London: SAGE Publications, 2009.

21. Fortes MB, Di Felice U, Dolci A, Junglee NA, Crockford MJ, West L, Hillier-Smith R, Macdonald JH, Walsh NP. Muscle damaging exercise increases heat strain during subsequent exercise heat stress. Med Sci Sports Exerc 45: 1915-1924, 2013.

22. Freeman BC, Morimoto RI. The human cytosolic molecular chaperones Hsp90, Hsp70 (Hsc70) and Hdj-1 have distinct roles in recognition of a non-native protein and protein refolding. Embo J 15: 2969-2979, 1996.

23. Friden J, Sjostrom M, Ekblom B. A morphological study of delayed muscle soreness. Experientia 37: 507-508, 1981.

24. Giraldo E, Martin-Cordero L, Garcia JJ, Gerhmann M, Multhoff G, Ortega E. Exercise-induced extracellular $72-\mathrm{kDa}$ heat shock protein
(Hsp72) stimulates neutrophil phagocytic and fungicidal capacities via TLR-2. Eur J Appl Physiol 108: 217-225, 2010.

25. Henderson B, Calderwood SK, Coates ARM, Cohen I, van Eden W, Lehner T, Pockley AG. Caught with their PAMPs down? The extracellular signalling actions of molecular chaperones are not due to microbial contaminants. Cell Stress Chaperon 15: 123-141, 2010.

26. Hillman A, Turner MC, Peart DJ, Bray JW, Taylor L, McNaughton L, Siegler J. A comparison of hyperhydration vs. ad libitum fluid intake strategies on measures of oxidative stress, thermoregulation and performance. Res Sports Med 21: 305-317, 2013.

27. Hillman AR, Vince RV, Taylor L, McNaughton L, Mitchell N, Siegler J. Exercise-induced dehydration with and without environmental heat stress results in increased oxidative stress. Appl Physiol Nutr Metab 36: 698-706, 2011.

28. Huang G, Shi LZ, Chi H. Regulation of JNK and p38 MAPK in the immune system: Signal integration, propagation and termination. Cytokine 48: 161-169, 2009.

29. Huang W, Tang Y, Li L. HMGB1, a potent proinflammatory cytokine in sepsis. Cytokine 51: 119-126, 2010.

30. Jones AM. Middle and Long Distance Running. In: Sport and Exercise Testing Guidelines. The British Association of Sport and Exercise Sciences Guide, Volume One: Sports Testing, edited by Winter EM, Jones AM, Davison RC, Bromley PD, and Mercer TH. London: Routledge, 2007, p. 147-154.

31. Lamprecht M, Oettl K, Schwaberger G, Hofmann P, Greilberger JF. Protein modification responds to exercise intensity and antioxidant supplementation. Med Sci Sport Exerc 41: 155-163, 2009.

32. Lee BJ, Emery-Sinclair EL, Mackenzie RW, Hussain A, Taylor L, James RS, Thake CD. The impact of submaximal exercise during heat and/or hypoxia on the cardiovascular and monocyte HSP72 responses to subsequent (post 24 h) exercise in hypoxia Extrem Physiol Med 3: 15, 2014.

33. Lee WC, Wen HC, Chang CP, Chen MY, Lin MT. Heat shock protein 72 overexpression protects against hyperthermia, circulatory shock, and cerebral ischemia during heatstroke. J Appl Physiol 100: 2073-2082, 2006.

34. Liu Y, Lormes W, Baur C, Opitz-Gress A, Altenburg D, Lehmann M, Steinacker JM. Human skeletal muscle HSP70 response to physical training depends on exercise intensity. Int J Sports Med 21: 351-355, 2000 .

35. Lorenzo S, Minson CT, Babb TG, Halliwill JR. Lactate threshold predicting time-trial performance: impact of heat and acclimation. $J$ Appl Physiol 111: 221-227, 2011.

36. Mahoney DJ, Carey K, Fu MH, Snow R, Cameron-Smith D, Parise G, Tarnopolsky MA. Real-time RT-PCR analysis of housekeeping genes in human skeletal muscle following acute exercise. Physiol Genomics 18: 226-231, 2004.

37. Marcora SM, Bosio A. Effect of exercise-induced muscle damage on endurance running performance in humans. Scand J Med Sci Sports 17: 662-671, 2007.

38. Marshall HC, Campbell SA, Roberts CW, Nimmo MA. Human physiological and heat shock protein 72 adaptations during the initial phase of humid-heat acclimation. J Therm Biol 32: 341-348, 2007.

39. McClung JP, Hasday JD, He JR, Montain SJ, Cheuvront SN, Sawka MN, Singh IS. Exercise-heat acclimation in humans alters baseline levels and ex vivo heat inducibility of HSP72 and HSP90 in peripheral blood mononuclear cells. Am J Physiol Regul Integr Comp Physiol 294: R185R191, 2008.

40. Mestre-Alfaro A, Ferrer MD, Banquells M, Riera J, Drobnic F, Sureda A, Tur JA, Pons A. Body temperature modulates the antioxidant and acute immune responses to exercise. Free Radical Res 46: 799-808, 2012.

41. MetOffice. Bedford Climate 1981-2010. http://www.metoffice.gov.uk/ public/weather/climate/gcr8t7h4n. [11/11, 2014].

42. Moir H, Hughes MG, Potter S, Sims C, Butcher LR, Davies NA, Verheggen K, Jones KP, Thomas AW, Webb R. Exercise-induced immunosuppression: roles of reactive oxygen species and 5'-AMP-activated protein kinase dephosphorylation within immune cells. J Appl Physiol 108: 1284-1292, 2010.

43. Montain SJ, Latzka WA, Sawka MN. Impact of muscle injury and accompanying inflammatory response on thermoregulation during exercise in the heat. J Appl Physiol 89: 1123-1130, 2000. 
44. Moran DS, Eli-Berchoer L, Heled Y, Mendel L, Schocina M, Horowitz M. Heat intolerance: does gene transcription contribute? J Appl Physiol 100: 1370-1376, 2006.

45. Morton JP, MacLaren DP, Cable NT, Bongers T, Griffiths RD, Campbell IT, Evans L, Kayani A, McArdle A, Drust B. Time course and differential responses of the major heat shock protein families in human skeletal muscle following acute nondamaging treadmill exercise. $J$ Appl Physiol 101: 176-182, 2006.

46. Morton JP, Maclaren DP, Cable NT, Campbell IT, Evans L, Kayani AC, McArdle A, Drust B. Trained men display increased basal heat shock protein content of skeletal muscle. Med Sci Sports Exerc 40: $1255-1262,2008$.

47. Neubauer O, Sabapathy S, Lazarus R, Jowett JBM, Desbrow B, Peake JM, Cameron-Smith D, Haseler LJ, Wagner KH, Bulmer AC. Transcriptome analysis of neutrophils after endurance exercise reveals novel signaling mechanisms in the immune response to physiological stress. $J$ Appl Physiol 114: 1677-1688, 2013.

48. Nielsen VG, Webster RO. Inhibition of human polymorphonuclear leukocyte functions by ibuprofen. Immunopharmacol 13: 61-71, 1987.

49. Noble EG, Milne KJ, Melling CW. Heat shock proteins and exercise: a primer. Appl Physiol Nutr Metab 33: 1050-1065, 2008.

50. Ortega E. Neuroendocrine mediators in the modulation of phagocytosis by exercise: physiological implications. Exerc Immunol Rev 9: 70-93, 2003.

51. Park KS, Sedlock DA, Navalta JW, Lee MG, Kim SH. Leukocyte apoptosis and pro-/anti-apoptotic proteins following downhill running. Eur J Appl Physiol 111: 2349-2357, 2011.

52. Paulsen G, Vissing K, Kalhovde JM, Ugelstad I, Bayer ML, Kadi F, Schjerling P, Hallen J, Raastad T. Maximal eccentric exercise induces a rapid accumulation of small heat shock proteins on myofibrils and a delayed HSP70 response in humans. Am J Physiol Regul Integr Comp Physiol 293: R844-R853, 2007.

53. Pyne DB, Smith JA, Baker MS, Telford RD, Weidemann MJ. Neutrophil oxidative activity is differentially affected by exercise intensity and type. J Sci Med Sport 3: 44-54, 2000.

54. Richter K, Buchner J. Hsp90: Chaperoning signal transduction. J Cell Physiol 188: 281-290, 2001.

55. Sawka MN, Burke LM, Eichner ER, Maughan RJ, Montain SJ, Stachenfeld NS. Exercise and fluid replacement. Med Sci Sports Exerc 39: 377-390, 2007.

56. Sawka MN, Leon LR, Montain SJ, Sonna LA. Integrated physiological mechanisms of exercise performance, adaptation, and maladaptation to heat stress. Compr Physiol 1: 1883-1928, 2011.

57. Schmittgen TD, Livak KJ. Analyzing real-time PCR data by the comparative CT method. Nat Protoc 3: 1101-1108, 2008.
58. Selkirk GA, McLellan TM, Wright HE, Rhind SG. Expression of intracellular cytokines, HSP72, and apoptosis in monocyte subsets during exertional heat stress in trained and untrained individuals. Am J Physiol Regul Integr Comp Physiol 296: R575-R586, 2009.

59. Steensberg A, Keller C, Starkie RL, Osada T, Febbraio MA, Pedersen BK. IL-6 and TNF- $\alpha$ expression in, and release from, contracting human skeletal muscle. Am J Physiol Endocrinol Metab 283: E1272-E1278, 2002.

60. Sureda A, Tauler P, Aguilo A, Cases N, Fuentespina E, Cordova A, Tur JA, Pons A. Relation between oxidative stress markers and antioxidant endogenous defences during exhaustive exercise. Free Radical Res 39: 1317-1324, 2005

61. Taipale M, Jarosz DF, Lindquist S. HSP90 at the hub of protein homeostasis: emerging mechanistic insights. Nature Rev Mol Cell Biol 11: 515-528, 2010.

62. Taylor L, Midgley AW, Chrismas B, Madden LA, Vince RV, McNaughton LR. Daily quadratic trend in basal monocyte expressed HSP72 in healthy human subjects. Amino Acids 38: 1483-1488, 2010.

63. Thompson HS, Maynard EB, Morales ER, Scordilis SP. Exerciseinduced HSP27, HSP70 and MAPK responses in human skeletal muscle. Acta Physiol Scand 178: 61-72, 2003.

64. Tintinger GR, Theron AJ, Anderson R, Ker JA. The anti-inflammatory interactions of epinephrine with human neutrophils in vitro are achieved by cyclic AMP-mediated accelerated resequestration of cytosolic calcium. Biochem Pharmacol 61: 1319-1328, 2001

65. Van Wijck K, Lenaerts K, Van Bijnen AA, Boonen B, Van Loon LJC, Dejong CHC, Buurman WA. Aggravation of exercise-induced intestinal injury by ibuprofen in athletes. Med Sci Sports Exerc 44: 2257-2262, 2012 .

66. Vissing K, Bayer ML, Overgaard K, Schjerling P, Raastad T. Heat shock protein translocation and expression response is attenuated in response to repeated eccentric exercise. Acta Physiol 196: 283-293, 2009.

67. Walsh NP, Gleeson M, Shephard RJ, Gleeson M, Woods JA, Bishop NC, Fleshner M, Green C, Pedersen BK, Hoffman-Goete L, Rogers CJ, Northoff H, Abbasi A, Simon P. Position statement. Part one: Immune function and exercise. Exerc Immunol Rev 17: 6-63, 2011.

68. Walsh NP, Whitham M. Exercising in environmental extremes-A greater threat to immune function? Sports Med 36: 941-976, 2006

69. Walsh RC, Koukoulas I, Garnham A, Moseley PL, Hargreaves M, Febbraio MA. Exercise increases serum Hsp72 in humans. Cell Stress Chaperon 6: 386-393, 2001.

70. Young AJ, Sawka MN, Epstein Y, Decristofano B, Pandolf KB. Cooling different body surfaces during upper and lower body exercise. $J$ Appl Physiol 63: 1218-1223, 1987. 